(= Durchschnitt von Feld-und Versuchsmaterial) und im durchschnittlichen Minutengemelk um I 7 Prozent Darüber hinaus wurde das Geburtsgewicht der $F_{1}$-Kälber erhöht. Bei Mastbullen führte eine geringere Fleischfülle bei $F_{1}$-Bullen zu einer schlechteren Bezahlung als bei Mastbullen reinrassig deutscher Herkunft (- - , Io DM/kg Lebendgewicht).

Wenn die Verwendung von $H F$-Bullen in der deutschen Schwarzbuntzucht ökonomisch sinnvoll sein soll, dann muss die Steigerung der Milchleistung die aufgetretenen und ökonomisch bedeutenden Nachteile dieser Zuchtmassnahme (höherer Nährstoffbedarf für Erhaltung und Foetusausbildung, schlechtere Bezahlung von Mastbullen) mehr als nur ausgleichen.

Uber Berechnungen von Deckungsbeiträgen ergab sich, dass bei einer Mehrleistung von rd. ro $\mathrm{kg}$ FCM je $\mathrm{kg}$ höheres Lebendgewicht eine Wettbewerbsgleichheit zwischen $\mathrm{F}_{1}$-Kühen ( $H F \times$ $D S B)$ und Deutschen Schwarzbunten gegeben ist. Wird diese Differenz zugunsten der $F_{1}$-Tiere überschritten, dann ist die Einkreuzung ökonomisch sinnvoll.

\title{
GeNETIC EVOLUTION OF CATTLE FOR BEEF PRODUCTION IN NEW ZEALAND
}

\author{
A. H. CARTER. - Ministry of Agriculture and Fisheries, Ruakura Animal Research Station, \\ Hamilton (New Zealand).
}

Although the trials reported vary widely in design, in genetic sampling and environmental conditions and hence in the generality of their findings, the following conclusions seem warranted in the New Zealand farming situation.

i) Relative to the Angus, the Friesian produces 20-30 p. Ioo more and the Hereford 5-10 p Ioo more final liveweight and carcass weight when slaughtered off pasture at 1 8-22 months of age. Approximately half this superiority is manifested in corresponding Angus crosses.

ii) In terms of weaning performance the Friesian dam is greatly superior, the Hereford slightly inferior, to the Angus.

iii) Heterosis in growth rate is of the order of $5 \mathrm{p}$. Ioo in crosses among the Angus, Hereford and Friesian.

iv) Dairy and dairy $\times$ beef breed carcasses contain proportionately more bone and consequently less meat than those from British beef breeds. Differences in dressing percentage are not consistent but tend to favour the beef breeds.

v) As a crossing sire for meat production from Jersey cows, the Charolais is superior to the Hereford but not significantly better than the Friesian, despite its higher lean meat yield.

Further information is needed on the lifetime calf production efficiency of the Friesian and Friesian-cross cow under hill country conditions and on the merit of Charolais crosses in suckler beef herds. Very preliminary results suggest that some of the other large European breeds may have potential in improving beef productivity from both dairy and suckler herds. Efficient exploitation of breed resources - through breed substitution, synthesising of new breed combinations or systematic crossbreeding-clearly demands more detailed knowledge of general and specific combining abilities. Effective oestrous control in beef herds will facilitate artificial breeding and so permit realisation of the benefits and flexibility of crossbreeding systems.

A consistent finding in those experiments where sires were identified has been the wide range in progeny performance of individual sires within breeds, usually greater than breed differences themselves. This pinpoints the very great importance of sound selection on performance merit, whatever the breed or breeding system.

\section{POSSIBILITY OF ESTIMATING HETEROSIS}

\section{WHEN THE EXTRANEOUS BREED IS IMPORTED BY MEANS OF SEMEN}

\section{E. A. Fimland. - Agricultural University of Norway, Aas-NLH, Norway.}

Exchanging deepfrosen semen may be a valuable tool for utilizing different breeds as potential breeding resources.

Imported semen of dairy bulls of extraneous breeds can be utilized as follows :

I. Importation of positive genes for further additive breeding work.

2. Enhancing the producing ability of the native population by means of exploiting any effect of heterosis. 
In order to utilize these objectives in an optimal way, it is of importance to obtain knowledge about the necessary crossbreeding parameters. In many cases, females of the extraneous breed are not available in the country considered. This makes it difficult to obtain estimates of the needed crossbreeding parameters. By utilizing a modern AI breeding program, however, an experiment can be planned in such a way that crossbreeding parameters of interest can be estimated. The experimental plan necessitates the following steps :

I. Selection of bulls within extraneous populations according to their proves.

2. Importation of semen from the selected bulls.

3. The imported semen doses are inseminated on elite cows in the native breeding population.

4. Young bulls of $F_{1}$ are progeny tested.

5. Young bulls of three-quarter of the extraneous breed are produced by inseminating unselected $F_{1}$-daughters with the imported semen.

6. Young bulls of three-quarter of the extraneous breed are progeny tested.

7. The regular AI breeding programme of the native breeding population yields groups of control.

By utilizing production records of cows with different proportion of the extraneous breed, the data can be used to estimate the following parameters :

I. The difference between the imported bulls of the extraneous breed and the contemporary native elite bulls in general combining ability.

2. The magnitude of the heterotic effect.

Thus, the crossbreeding parameters of actual interest for the native breeding population can be estimated.

\section{VORLÄUFIGE ERGEBNISSE AUS DER KREUZUNG VON ROTBUNTEN HOLSTEIN-FRIESIAN MIT FLECKVIEH IN BAYERN}

G. Averdunk, A. GotTschalk, H. KRäusslich, E. Schwarz. - Bayerische Landesanstalt f. Tierzucht, 8011 Grub b. München (BRD).

Ưber vorläufige Ergebnisse der Leistungen der Kreuzungen von Rotbunten Holstein-Friesian Bullen und Fleckviehkihen wird berichtet. In der I. Laktation zeigten die $F_{1}$-Tiere im Vergleich zu reinrassigen Fleckvieh-Stallgefährtinnen eine Differenz von $+700 \mathrm{~kg}$ Milch, $+25 \mathrm{~kg}$ Fett und - o,05 Prozent Fett. Die gewogene Differenz nach dem Contemporary Comparison war mit + $594 \mathrm{~kg} \mathrm{Milch},+20 \mathrm{~kg}$ Fett und - 0.08 Prozent Fett etwas geringer. Das Erstekalbealter der $\mathrm{F}_{1}$-Tiere war um I.8 Monate niedriger, während die Melkbarkeit, Euterform und Körpergrösse deutlich höher lagen. Die Konformation der Kühe und Bullen war im Hinblick auf die Fleischproduktion negativ beeinflusst.

Die Ergebnisse der Fleischleistungsprüfung an 2 Stationen zeigten bei den $F_{1}$-Bullen eine grössere Frühreife wie bei den Flechviehvergleichsbullen. Bei der Mastprüfung bis zum 50o. Lebenstag hatten die $F_{1}$-Bullen ein um $I_{3} \mathbf{~ k g}$ geringeres Gewicht bzw. ein Unterschied von $34 \mathrm{~g}$ Zunahme im Prüfungsabschnitt vom I I2. - 500. Tag. Auf höherem Zunahmeniveau betrug die Differenz in der Zunahme $67 \mathrm{~g}$. Die $F_{1}$-Schlachtkörper hatten mehr Beckenhöhlen- und Nierenfett (1.4 kg), einen geringeren Pistolenanteil (1.2 Prozent eine geringere Rückenmuskelfläche $\left(8.7 \mathrm{~cm}^{2}\right.$ an 8./9. Rippe) und eine grössere Schlachtkörperlänge $(1.9 \mathrm{~cm})$. Die Schlachtkörper waren auf dem Schlachtviehmarkt weniger akzeptabel und wurden teilweise diskriminiert.

Der relative Anteil von Heterosis an den Leistungsunterschieden der $F_{1}$-Tiere kann zum gegenwärtigen Stand des Versuches noch nicht beurteilt werden.

\section{A SCHEME FOR COMPARISON}

\section{OF DIFFERENT STRAINS OF FRIESIANS}

\section{H. SkJervold. - The Agricultural University of Norway, Aas-NLH, Norway.}

During the last decades large effort has been made in developing efficient breeding schemes in various populations in dairy cattle.

An important part of such breeding schemes is a continuous measuring of achieved genetic 